\title{
Kurumsal Girişimcilik ve Yeniliğin İşletme Performansına Etkisi*
}

\begin{abstract}
do
Suat OKAY ${ }^{* *}$

Mahmut TEKIN ${ }^{* * *}$

$\ddot{O}_{z}$

Kurumsal girişimcilik; kurumun daha ileriye giderek gelişmesini sağlamak üzere yenilikçi fikirler üreterek faydalı olabilecek girişimler yapmayı sağlayan girişimcilik türüdür. Kurumsal girişimcilikle kurumda rekabet artacağl için çallşanlar da işlerine önem vererek daha etkili ve verimli çalışabilecektir. Bu girişimcilik türü, kurum içinde yapılacak yenilikçi hareket ve fikirlerle kurumsal yapıyı olumlu yönde değiştirir. Bu çalışmada, kurumsal girişimcilik kavramı ve yeniliğin sağhlk işletmelerinde uygulanabilirliği ve işletme performansı ile iliş̧kisi incelenmiştir. Araştırmanın anketi Batman'da yer alan bir kamu ve 4 özel hastane çalışanlarına uygulanmıştır. Araştırmanın sonucunda, sağlık işletmelerinde kurumsal girişimcilik ve yenilik kavramının henüz tam anlamıyla bilinmediği ve kurumsal girişimcilik ve yenilik kavramının sağlık işletmelerinin performansı üzerinde olumlu bir etkiye sahip olduğu belirlenmiştir. Araştırmanın sonuçlarından yola çıkarak sağlık alanında kurumsal girişimcilik ve yenilik faaliyetlerinden yararlanmak için inovasyon, risk yönetimi, AR-GE, stratejik yönetim gibi alanlarda hizmet içi eğitimler planlanmalı ve sürekli eğitim ile güncellenmelidir.
\end{abstract}

Anahtar Sözcükler: Girişimcilik, Kurumsal Girişimcilik, Yenilik, İşletme performansı.

\section{The Effect of Corporate Entrepreneurship and Innovation on Business Performance}

\begin{abstract}
Corporate entrepreneurship; it is the type of entrepreneurship that makes it possible to make initiatives that can be useful by producing innovative ideas in order to enable the institution to progress further. With corporate entrepreneurship, competition in the institution will increase and employees will be able to work more effectively and efficiently by giving importance to their work. This type of entrepreneurship changes the institutional structure positively with innovative movements and ideas within the institution. In this study, the concept of corporate entrepreneurship and its relation to innovativeness, applicability in health enterprises and business performance are examined. The survey's questionnaire was applied to a public and 4 private hospital employees in Batman. As a result of the research, it was determined that the concept of corporate entrepreneurship and innovation in health enterprises is not yet fully understood and that the concept of corporate entrepreneurship and innovation has a positive influence on the performance of health enterprises. By going out of the results of the research, to benefit from corporate entrepreneurship and innovation activities in the field of health, in-service trainings in areas such as innovation, risk management, AR-GE and strategic management should be planned and updated with continuous training.
\end{abstract}

Keywords: Entrepreneurship, Corporate Entrepreneurship, Innovation, Business Performance.

\footnotetext{
* Bu çalışma, 17-20 Ekim 2019 tarihinde Bodrum/Muğla'da düzenlenen 4. Uluslararası Girişimcilik, İstihdam ve Kariyer Kongresi'nde bildiri olarak sunulmuştur.

** ORCID Öğr. Gör. Batman Üniversitesi, SBMYO, Muhasebe ve Vergi Uygulamaları, suat.okay@batman.edu.tr *** ORCID Prof. Dr., Selçuk Üniversitesi, İIBB, İşletme, mahtekins@gmail.com
} 


\section{Extended Abstract}

Corporate entrepreneurship is the type of entrepreneurship that makes it possible to make initiatives that can be useful by producing innovative ideas in order to enable the institution to progress further. With corporate entrepreneurship, competition in the institution will increase and employees will be able to work more effectively and efficiently by giving importance to their work. This type of entrepreneurship changes the institutional structure positively with innovative movements and ideas within the institution. With the encouragement of corporate entrepreneurship, innovative and entrepreneurial organizational structures may emerge. In this context, organizational culture is among the important components of corporate entrepreneurship in individual values and creativity.

In this study, the concept of corporate entrepreneurship and its relation to innovativeness, applicability in health enterprises and business performance are examined. The survey's questionnaire was applied to a public and 4 private hospital employees in Batman. As a result of the research, it was determined that the concept of corporate entrepreneurship and innovation in health enterprises is not yet fully understood and that the concept of corporate entrepreneurship and innovation has a positive influence on the performance of health enterprises. By going out of the results of the research, to benefit from corporate entrepreneurship and innovation activities in the field of health, in-service trainings in areas such as innovation, risk management, AR-GE and strategic management should be planned and updated with continuous training. Innovation studies should be supported and encouraged. Efforts should be made to raise awareness at all levels of the management levels of institutions and businesses in corporate entrepreneurship and innovation activities in order to provide quality service to meet customer demands and to create value in the market by providing competitive advantage. As a result of the study, a general evaluation was made and recommendations were presented. 


\section{Giriş}

Girişimcilik, günümüzde üzerinde pek çok çalışma yapılan bir alan haline gelmiştir. Fakat girişimcilik kavramının hangi bileşenlerden meydana geldiği konusunda hâlâ belirsizlikler mevcuttur (Landström vd, 2012: 1154). Ekonomilerde, girişimcilik tanımı iki türlüdür. Bunlardan birincisi, 'yeni bir işe başlamak' iken, diğeri 'kendi işini yapmak, kendi işine sahip olmaktır'. Hart 2003 yılındaki çalışmasında, girişimciliği; yeni işler geliştirmek için başlangıç ve gelişim süreci olarak tanımlamıştır (Aktaran: Gries vd., 2011: 216, 217). Share ve Venkataraman, 2000 yılında girişimcilik kavramını tanımlarken; girişimcilik, gelecekteki ürünlerin ve hizmetlerin oluşumunu etkileyecek olan firsatların, kimler tarafından, nasıl ve ne zaman keşfedileceği ve geliştirileceği ile ilgili çalışmalar olarak ifade etmiştir (Aktaran: Landström vd, 2012: 1154).

Kurumsal girişimciliğe yönelik çalışmaların 20. yüzyılın sonlarına doğru arttığı görülmektedir. İşletmelerin kendi içinde yenilikçilik yaparak girişimciliği geliştirmesi olarak ifade edilen bu kavram, girişimcilik faaliyetlerini üst kademe yöneticilerine bağlı bir fonksiyon olmaktan çıkarıp, alt kademelere doğru yönlendirerek yukarıdan aşağıya doğru bir yönelim sağlamıştır. Yenilikçilik ve rekabetçiliğe bağlı olarak girişimciliğin seviye ve içeriğinde yaşanan bu değişimler, kurumsal girişimciliğin (corporate entrepreneurship) örgüt seviyesinde girişimcilik eğilimi (firm-level entrepreneurial orientation), kurum içi girişimcilik (internal corporate venturing), iç girişimcilik (intrapreneurship) gibi kavramların ortaya çıkmasına neden olmuştur (Morrison, Rimmington ve Williams, 2001: 54-55; Morris ve Kuratko, 2002: 31; Ağca, 2005:1).

Günümüz işletmelerinde rekabetçi ve yenilikçi olabilmek için kurumsal girişimcilik işletmelerde önemli bir stratejik araç haline gelmiştir. Kurumsal girişimcilik ve yeniliğin işletme performansı arasındaki ilişkiyi ölçmeyi hedefleyen bu çalışma dört bölümden oluşmaktadır. Çalışmanın birinci bölümünde, genel olarak girişimcilik ve kurumsal girişimcilikle ilgili kavramsal bir çerçeve oluşturulmuştur. Kurumsal girişimcilik kavramları ve özellikleri ile ilgili literatür çalışmaları yapılmıştır. Kurumsal girişimcilikle ilgili ulusal ve uluslararası alanda yapılmış olan tanımlara ve çalışmalara yer verilmiştir. Kurumsal girişimciliğin temel boyutları olan; "yenilikçilik", "risk alma", "proaktiflik", "örgütsel yenilenme" ve "rekabetçi agresiflik" boyutları incelenmiştir. Çalışmanın ikinci bölümünde ise yenilikçilik kavramları, yeniliğin tanımı yapılarak türleri ve boyutları açıklanmış ve yenilikçilik incelenmiştir. Çalışmanın üçüncü bölümünde performans kavramına yer verilmiş, bu bölümde işletme performansı; kurumsal girişimcilik faaliyetlerinin kârlılık, büyüme, maliyet, satış geliri, pazar payı, yatırımın geri dönüşü ve doluluk oranı gibi finansal; yenilik, kalite-müşteri boyutu, verimlilik, çalışanların yaşam kalitesi, sosyal sorumluluk ve sosyal kabul gibi finansal olmayan performans verileri incelenmiştir. Çalışmanın dördüncü bölümünde, işletmelerde yürütülen kurumsal girişimcilik ve yenilik faaliyetlerinin, işletme performansına etkisini tespit etmeye yönelik araştırmanın metodolojisi incelenmektedir. Ayrıca bu bölümde, araştırmanın önemi, amaçları, hipotezleri, örnekleme süreci, veri toplama yöntemi süreci ve araçlarına ilişkin bilgilere yer verilmektedir. Batman ilinde faaliyet gösteren sağlı kuruluşlarında gerçekleştirilen araştırmanın yöntemi ve verilerin analizinde kullanılacak olan istatistiksel teknikler açıklanmaktadır. 


\section{Girișimcilik ve Kurumsal Girișimcilik}

\subsection{Girişimcilik}

Girişimcilikle ilgili yapılan tanımlarda genel olarak akademisyenler tarafından üzerinde görüş birliğine varılan temel noktalar; inisiyatif alma, kaynakları ve koşulları kullanılabilir değerlere dönüştüren sosyal ve ekonomik alanlarda düzenleme yapma, risk ve başarısızlığı kabul etme yer almaktadır (Ağca, 2005:7; Kao, 1989:91). Girişimcilik, bir iş fikrine sahip olarak pazardaki firsatları değerlendirmek ve mal ve hizmet üretmek amaciyla üretim faktörlerinin bir araya getirilerek, işletmesiyle ilgili faaliyetler bütünüdür (Tekin, 2016:3). Girişimcilik, ekonomik büyüme ve gelişme sürecinde işletmelerin rekabet avantajı elde etmeleri ve sürekliliklerini sağlamaları gibi birçok nedenden dolayı önemli bir unsur olarak değerlendirilmektedir. Girişimcilik, kaynakları ekonomik olarak seferber etme, harekete geçirme faaliyetleridir (Aytaç, 2006:141; Hisrich, Peters ve Shepherd, 2005:8). Girişimci, mal ve hizmet üretimini gerçekleştirebilmek için riski üstlenerek doğal kaynak, sermaye, emek gibi üretim faktörlerini bir araya getirip faaliyete geçiren kişi olarak tanımlanabilir (Tekin, 2014:3). Girişimci bir bakış açısıyla, herhangi bir kişi risk alarak iş kurarak bunu uygulayabilir. Bu bakış açısıyla, gerek işletme içinde gerekse işletme dışında kâr amaçlı veya kâr amaçsız girişimler kurulabilir. Girişimcilik kavramında amaç, yenilikçi fikirleri örgütsel gerçeklere uygun hale getirip uygulayabilmektir. Bu bağlamda, girişimciler yeni bir işletme kurarak veya mevcut bir işletme içinde eskiyi ortadan kaldırarak yenilikler yaratmaya çalışırlar. Girişimci düşünme ve davranma, her ülkede ve her düzeydeki işletmede işlerin uygulama şeklini ve süreçlerini değiştirmeyi amaçlar. Günümüzde girişimcilik bağımsız bir kavram olmaktan ziyade işletme organizasyonu kültüründen kök alan bir süreç olarak ifade edilebilmektedir (Fiş ve Wasti, 2009:132).

\subsection{Kurumsal Girişimcilik}

Genel anlamda "mevcut bir işletme içerisinde girişimcilik" olarak ifade edilen kurumsal girişimcilik, literatürde bir kurumun girişimciliği; risk alma, inovasyon, proaktivite ve agresif rekabet yönelimlerini içeren örgütsel yönelime eş değer olarak ifade edilir (Bulut vd., 2008: 1390). Kurumsal girişimcilik, girişimcilik eğiliminin bir parçası ve eyleme dönüştürülmüşs şekli olarak bir işletmenin tüm yenilikçilik, stratejik yenilenme ve yeni iş kurma faaliyetlerinin tamamı olarak tanımlanmaktadır (Zahra, 1996:1715).

Günümüzde sektörler kısıtlı kaynaklar, yaşanan teknolojik gelişmeler, ürünlerin kısa ömür döngüleri ve küreselleşme ile artan yoğun rekabete göre şekillenmektedir. Bundan ötürü, işletmeler hızlı bir değişime ihtiyaç duymaktadır. Mevcut işlerinde veya ek olarak yenilik gerçekleştiren üreticiler ekonomik büyüme üzerinde her zaman olumlu etki yaratmaktadır. Yenilik ve yeniliğin getirdiği değişime açık olan işletmeler ayrıca verimlilik ve rekabet edebilirlik noktasında da kritik rol üstlenirler. Klasik yönetim anlayışı ve doğurduğu sorunların oluşturduğu yetersizlik, işletmelerdeki değişim arzusu, pazarda kalabilmek için verilen yaşam mücadelesi ve gerektirdiği gelişim, kurumsal girişimciliğin önemini günümüz şartlarında daha da arttırmıştır (Zehir vd., 2012:924-925). İşletmelerin faaliyetlerini devam ettirebilmesi ve rekabet edebilmesi için bir çözüm olarak düşünülen kurumsal girişimcilik kavramı; 1980 sonları ve 1990 başlarında dikkat çekmeye başlamıştır (Thomson ve McNamara, 2001: 671). Kurumsal girişimcilik kavramı ilk zamanlarda yaratıcılık ve inovasyon konularını fazla önemsemeyen büyük işletmeler için sorun olmaktaydı. Klasik işletmeler 1950-1960'lı yıllarda daha tutucu tavır sergileyen 1980'li yıllarda inovasyon ve risk almaya gönüllü olmayan kısa vadeli düşünen işletmeler halini almıştır. Fakat sonraki süreçte 'kurumsal' kavramı ile 
'girişimcilik' kavramının bütünleşmesi ile yaratıcı ve inovatif yollara başvuran, çalışan ve iştiraklerine gelir sağlamayı amaçlayan işletmeler meydana gelmiştir (Sathe, 2003:1-2).

Kurumsal girişimcilik kavramı; iç kurumsal girişimcilik, girişimci stratejik yönelim, kurumsal iş kurma, stratejik duruş, yaygın girişimcilik, stratejik yenilenme, iç girişimcilik, girişimcilik yönelimi gibi değiştirilerek kullanılan farklı terimler olarak da kullanılmaktadır (Fiş ve Wasti, 2009:131). İşletmelerin stratejik plan ve hedeflerine ulaşması ve değer yaratabilmesi için kurumsal girişimcilik faaliyetlerine önem gösterip daha inovatif ve proaktif eylemler yapması gerekmektedir. İnovatif ve proaktif eylemler işletmeler için rekabetle ilgili yeni ufukların doğmasına yardımcı olur. Kurumsal girişimcilik inovasyon, iş geliştirme ve stratejik yenilenme gibi kavramlardan meydana gelir. İşletmelerde kurumsal girişimcilik, inovasyon çalışmalarını ve değişimi desteklemelidir. Yöneticiler, sadece planlar ve kontroller bağlamında işletmeyi yönetmemeli, sektördeki ve pazardaki beklentileri karşılayabilecek işlemleri gerçekleştirmelidir (Martinez vd., 2010:2-3).

Kurumsal girişimcilik her zaman ekonomik gelişme ve refah ortamı sağlayabilmek içinde işletmeler için önemli bir öğe olmuştur. Kurumsal girişimcilik, mevcut işletmelerin yeni ürün, hizmet, teknoloji, yönetim stratejileri ve rekabet stratejisi geliştirmek gibi inovatif faaliyetler ve yeni iş girişimlerine fırsat doğurur (Zehir vd., 2012:926). Ayrıca, kurumsal girişimcilik, yeni ürünlerin ve yeni pazarların geliştirildiği ortamı ifade eden ve karlılığı arttırmak ve işletmenin rekabet düzeyini yükseltmek için mevcut organizasyonda yeni işler oluşturan bir süreçtir (Carrier, 1996: 6).

\subsubsection{Kurumsal Girişimciliğin Boyutları}

Kurumsal girişimcilik çalışmaları, çalışanların fikir ve düşüncelerini rahat bir biçimde ifade edebildikleri ve uygulamada da gerçekleştirebildikleri işletmelerde gelişir. Kurumsal girişimcilik çalışmalarının başarısı için işletme stratejisi ve işletmenin bütünleşmesi gerekir (Goodale vd., 2011: 116). Kurumsal girişimcilik, büyük işletmelerin büyüme oranlarının artmasına ve faaliyetlerini devam ettirebilmesine olanak sağlarken, aynı zamanda küçük işletmelerinde gelişmesine ve rekabet gücünün artmasına katkıda bulunur (Zehir vd., 2012:925). Değişik büyüklükteki işletmelerde farklı gayelerle kullanılması sebebiyle, kurumsal girişimciliğin tanımlamasında olduğu gibi, boyutları da araştırmacılar tarafından farklı değişkenlerle ortaya konulmuştur.

Kurumsal girişimcilik ile ilgili yapılan akademik çalışmalar incelendiğinde ortaya çıkan sonuca göre kurumsal girişimciliğin boyutları; yenilikçilik (inovasyon), risk alma, proaktivite ve agresif rekabetçilik olarak ortaya çıkmıştır (Covin ve Slevin, 1991; Zahra, 1991; Zahra ve Covin, 1995; Lumpkin ve Dess, 1996; Dess vd., 2003; Hayton ve Kelley, 2006; Bulut vd., 2008:1395). 
Tablo 1: Kurumsal Girişimciliğin Boyutları

\begin{tabular}{|c|c|c|c|}
\hline NO & YAZAR & YIL & BOYUT \\
\hline 1 & Mintzberg & 1973 & $\begin{array}{c}\text { İnovasyon, Proaktivite, Merkeziyetçilik, Risk alma } \\
\text { Büyüme Oryantasyonu }\end{array}$ \\
\hline 2 & Miller ve Friesen & 1982 & İnovasyon, Risk alma \\
\hline 3 & Morris ve Paul & 1987 & İnovasyon, Risk alma, Proaktivite \\
\hline 4 & Covin ve Slevin & 1989 & İnovasyon, Proaktivite, Risk alma \\
\hline 5 & Guth ve Ginsberg & 1990 & İnovasyon, Yeni iș kurma, Stratejik Yenilenme \\
\hline 6 & Covin, Slevin, Covin & 1990 & İnovasyon, Proaktivite, Risk alma \\
\hline 7 & Covin ve Slevin & 1991 & İnovasyon, Risk alma, Proaktivite Agresif Rekabetçilik \\
\hline 8 & Zahra & 1991 & Formel, Informel \\
\hline 9 & Miles, Arnold,Thompson & 1993 & İnovasyon, Risk alma, Proaktivite \\
\hline 10 & Zahra & 1993 & İnovasyon, Yeni iş kurma, Stratejik Yenilenme \\
\hline 11 & Zahra ve Covin & 1995 & İnovasyon, Risk alma, Proaktivite \\
\hline 12 & Zahra & 1996 & İnovasyon, Yeni iş kurma, Stratejik Yenilenme \\
\hline 13 & Lumpkin ve Dess & 1996 & İnovasyon, Otonomi, Risk alma, Agresif Rekabetçilik, Proaktivite \\
\hline 14 & Zahra ve Neubaum & 1998 & İnovasyon, Risk alma, Proaktivite \\
\hline 15 & Barringer ve Bluedorn & 1999 & İnovasyon, Risk alma, Proaktivite \\
\hline 16 & Zahra ve Garvis & 2000 & İnovasyon, Risk alma, Proaktivite \\
\hline 17 & Zahra, Neubaum, Huse & 2000 & İnovasyon, Yeni iș kurma \\
\hline 18 & Lumpkin ve Dess & 2001 & Proaktivite, Agresif Rekabetçilik \\
\hline 19 & Saly & 2001 & İnovasyon, Risk alma, Proaktivite, Kurumsal yatırımlar, Yenilenme \\
\hline 19 & Kreiser, Marino, Weaver & 2002 & İnovasyon, Risk alma, Proaktivite \\
\hline 20 & Liu, Luo ve Shi & 2002 & İnovasyon, Risk alma, Proaktivite \\
\hline 21 & Antoncic ve Hisrich & 2003 & $\begin{array}{c}\text { İnovasyon, Yeni iş kurma, Örgütsel yenilenme, Risk alma, Proaktivite, } \\
\text { Agresif Rekabetçilik }\end{array}$ \\
\hline 22 & Chen, $\mathrm{Zu}$ ve Anquan & 2005 & İnovasyon, Yeni iş kurma \\
\hline 23 & Wiklund ve Shepherd & 2005 & İnovasyon, Risk alma, Proaktivite \\
\hline
\end{tabular}

Kaynak: (Bulut vd., 2008: 505-510)

\section{Yenilik}

İşletme bünyesinde birlikte performans sergileyen değişik düzeylerde bilgi ve deneyime vakıf personeli verimli ve etkin şekilde kullanabilmek adına gerçekleştirilen faydalı bilgi eğitimleri bütünü olarak ifade edilir (Durna, 2002:5). Yenilik yalnızca herhangi bir yeni bir fikir meydana getirmekten ibaret değildir. Ortaya çıkarılan fikir yalnızca kişinin bünyesinde kaldığında yenilikten çıkar ve genel itibar görmez. Üretilen fikir eyleme dönüştürülmeli ve uygulanmalı ve etkin bir şekilde kişilerce kullanılmalıdır. Üretilen fikrin uygulamada bir verim sağlayabiliyorsa yenilikçilik olarak tanımlanabilir. İfade edildiği gibi, yeni fikir sadece ortaya çıkarma ile yenilik olarak kabul edilmeyebilir. Yenilik fikrinin kabul edilmesi için toplum ve işletme için fayda sağlamalıdır (Johansson, 2013: 30).

Yeniliğin meydana gelmesi için yeni pazar, yeni ürün, yeni tedarikçi kaynağına sahip olmak, yeni üretim tasarımları ve yeniliği benimseyecek bir işletme gerekmektedir (Thakur vd., 2012:565). İşletmeler yenilik geliştirmek, yeni bir fikrin meydana getirerek ve uygulama aşamasını da gerçekleştirerek, çalışanlara sahip çıkmaya önem vermektedir (Van De Ven vd., 1999:149-180). Yenilik yalnızca teknik bir ifade olarak bilinmemelidir. Sosyal ve aynı zamanda ekonomik değer içeren bir terimdir. Yeniliğin kıstası bilimsel veya teknolojik değil, ekonomik ve sosyal ortamda gerçekleştirilen değişimdir (Drucker, 2014:785).

Yenilik çalışmaları yalnızca üretim sektöründe yapılmamaktadır, hizmet sektöründe de yenilik çalışmaları büyük önem arz etmektedir. Hizmet sektöründe ürünlerin ve hizmetlerin yenilenmesi ve yeniliklere açık olması sektörün hızlı gelişmesine neden olmaktadır. Yeni ürün ve hizmet çeşitliliğinin artış göstermesi, kaynakların sınırlı olması işletmeler arası rekabeti zorunlu ve önemli bir etken olarak ortaya çıkarmıştır. Rekabet ederek yaşam döngüsünü devam ettirmek ancak yenilikçilik yönetimi ve uyum çalışmaları ile sağlanabilir. Ürün ve süreçlerle ilgili yenilikçilik kabiliyeti işletme içi yenilikçilik yönetimi ve sektördeki teknolojik yenilikleri takip etmeyle direkt ilişkili olduğu görülmektedir (Baktır, 2005:5). 


\section{4. İşletme Performansı}

İşletme performansı, işletmenin amaçlarını hangi oranlarda gerçekleştirdiğini tespit etmek için değerlendirilmektedir (Bakoğlu, 2001: 39).

İşletmelerin faaliyetlerini devam ettirerek gelişebilmeleri, operasyonel, finansal ve çevresel performanslarına ilişkin alacakları geri bildirim ve bu geri bildirim sonucunda uyguladıkları eylemlere bağlıdır (Sheu ve Lo, 2005: 79-90). İşletme ve yönetiminin temelinde var olan performans kavramı, bir örgütün kaynaklarını etkin ve verimli bir biçimde kullanarak hedeflerine varabilme becerisidir (Boyne, 2003: 369).

Performans kavramının, amaçlanan hedefe yönelik bir başarı elde etmenin gerçekleştirilmek istenen eyleme yönelik etkinlik, etkililik, verimlilik, beceri ve memnuniyet gibi kavramlarla birlikte, gerçekleştirilmek istenen eylemlerin oranlarını belirleyici bir öğe olarak tanımlanmaktadır (Avcı ve Topaloğlu, 2008:339).

Performans ölçme, işletmenin pazardaki mevcut gelişmelere sadece izlemekle yetinmemesi için veri kaynağı olmakta ve gelişmelere olumlu veya olumsuz tepki verebilme yeteneğine etkisinin sebeplerini belirlemede büyük bir kaynak oluşturur (Mawer, 2003: 260).

İşletme performansını ölçmenin yararlarını ise aşağıdaki şekilde sıralanabilir (Baki ve Ustasüleyman 2001: 71):

- Örgütün nasıl işlediğini izleme imkânı tanıması,

- İşletmelere, sorunlarının kaynaklarını ve başarılarının veya başarısızlıklarının altında yatan temel nedenleri belirlemeye yönelik bilgi akışı sağlaması

- Muhtemel performans eksikliklerini belirlemeye yardımcı olması

- Ödüllendirilebilecek performansı belirlemede etkili olması

- İşletme planlarına yönelik, önceden belirlenmiş olan kaynak kullanımının ne derece verimli gerçekleştiğini belirlemeye imkân vermesi.

Finansal ölçümler, günümüz itibariyle demode olmuş ve istenilen sonuçlara ulaşılamamaktadır. Bu durumun sebebi ise ölçümlenen verilerin yetersiz ve kısıtlı veriler olmasıdır (Reiner, 2004: 1). Bu tür eksikliklerden ötürü son yıllarda işletme performansını ölçmede finansal göstergelerin yanında verimlilik, kalite, müşteri tatmini, müşteri sadakati, marka değeri, üretimde değer yaratma, teknolojik etkinlik, yeni ürün geliştirme, çalışma yaşamının kalitesi, pazar payı gibi yeni boyutlar da ölçümlerde değerlendirme kriterleri arasına girmiştir (Göztür, 2000: 4). Yukarıda ifade edilen boyutlar finansal olmayan performans verileri olarak ifade edilmektedir. Finansal olmayan ölçütler kullanmak da işletme performansını ölçülmesinde geliştirilen bir diğer teknik olarak kullanılmaktadır. Finansal performans ölçütleri, gelir, nakit akışı, aktif kârlılığ 1 ve özkaynak kârlılığı gibi ölçütlerden oluşmaktadır (Haber ve Reichel, 2005: 257).

\section{Kurumsal Girişimcilik ve Yeniliğin İşletme Performansı Üzerine Etkisi Bir Uygulama}

\subsection{Araştırmanın Amacı}

$\mathrm{Bu}$ çalışmanın amacı, farklı sektörlerde hizmet veren işletmelerin son yıllarda benimsedikleri ve yaygın olarak akademik çalışmaların gerçekleştirildiği kurumsal girişimcilik kavramının sağlık kurumu işletmelerinde kurumsal girişimcilik eğilimini tespit ederek, bu eğilimin işletmelerin yenilik ve performansları üzerinde etkisi olup olmadığını belirlemek amacıyla hazırlanmıştır. 


\subsection{Araștırmanın Kısıtları}

$\mathrm{Bu}$ çalışma, hastane sayısının kısıtlı olması, zaman ve maliyet kısıtlılıkları nedeniyle Batman il merkezinde hizmet veren hastanelerin yöneticileri ve idari çalışanları ile sınırlı tutulmuştur.

\subsection{Araştırmanın Hipotezleri}

Kurumsal girişimcilik ve yenilikçilik eğiliminin sağlık kuruluşlarındaki işletme performansını etkileyip etkilemediğinin araştırılması.

$\mathrm{Bu}$ temel araştırma sorusu çerçevesinde, kurumsal girişimcilik boyutları ve yenilikçiliğin işletme performansına etkisine ilişkin araştırmanın hipotezleri aşağıdaki şekilde belirlenmiştir: etkilidir.

$\mathrm{H}_{1 \mathrm{a}}$ : Yenilikçilik eğilimi, finansal performans üzerinde pozitif ve anlamlı düzeyde

$\mathrm{H}_{1 \mathrm{~b}}$ : Yenilikçilik eğilimi, finansal olmayan performans üzerinde pozitif ve anlamlı düzeyde etkilidir.

$\mathrm{H}_{2 \mathrm{a}}$ : Poaktiflik eğilimi, finansal performans üzerinde pozitif ve anlamlı düzeyde etkilidir. etkilidir.

$\mathrm{H}_{2 b}$ : Proaktiflik eğilimi, finansal olmayan performans üzerinde pozitif ve anlamlı düzeyde etkilidir.

$\mathrm{H}_{3 a}$ : Örgütsel yenilenme eğilimi, finansal performans üzerinde pozitif ve anlamlı düzeyde

$\mathrm{H}_{3 \mathrm{~b}}$ : Örgütsel yenilenme eğilimi, finansal olmayan performans üzerinde pozitif ve anlamlı düzeyde etkilidir.

$\mathrm{H}_{4 a}$ : Risk alma eğilimi, finansal performans üzerinde pozitif ve anlamlı düzeyde etkilidir. etkilidir.

$\mathrm{H}_{4 b}$ : Risk alma eğilimi, finansal olmayan performans üzerinde pozitif ve anlamlı düzeyde etkilidir.

$\mathrm{H}_{5 \mathrm{a}}$ : Rekabetçi agresiflik eğilimi, finansal performans üzerinde pozitif ve anlamlı düzeyde

$\mathrm{H}_{5 b}$ : Rekabetçi agresiflik eğilimi, finansal olmayan performans üzerinde pozitif ve anlamlı düzeyde etkilidir.

\subsection{Araştırmanın Örneklemi}

Araştırmanın evrenini Batman il merkezinde hastanelerde görev yapan sağlık çalışanı ve idari çalışanlar oluşturmaktadır. Batman il sağlık müdürlüğünden elde edilen verilere göre, Batman kamu hastanesi ve özel hastanelerinde çalışan sağlık ve idari personel sayısı 914 olarak verilmiştir. Yapılan anket çalışmalarında basit tesadüfi örneklem yöntemi seçilmiş olup \%90 güven düzeyinde $\% 5$ hata payı ile 400 anket oluşturulmuş fakat 294 adet anket geri dönüşümü sağlanmıştır. Yapılan analiz çalışması da bu sayıya göre yapılmıştır.

\subsection{Araştırmanın Yöntemi ve Kullanılan Ölçekler}

\subsubsection{Araştırmanın Yöntemi}

Araştırmanın yöntemi anket olup, yüz yüze anket tekniği uygulanmıştır. Araştırma verilerinin toplanmasında kullanılan anket formu üç kısımdan oluşmaktadır. Anket formunun ilk bölümünde katılımcıların demografik bilgilerine ilişkin ifadeler yer almaktadır. Anket formunun ikinci bölümünde yenilikçilik ölçmeye yönelik 6 ifade, üçüncü bölümünde kurumsal girişimciliği ölçmeye yönelik 21 ifade, anket formunun dördüncü kısmında ise çevrenin rekabetçi yapısına ilişkin algıyı belirlemeye yönelik 3 ifade yer almaktadır. Anket formunun beşinci bölümünde de, finansal ve finansal olmayan performans ölçümüne yönelik 10 ifade 
bulunmaktadır. Anket formunun ikinci bölümünde yer alan ifadelerin derecelendirilmesinde 5'li Likert ölçeği kullanılmıştır. Ölçekte, 1-Kesinlikle katılmıyorum, 2-Katılmıyorum, 3Kararsızım, 4- Katılıyorum, 5-Kesinlikle katılıyorum değerlendirmelerine karşılık gelmektedir. Anket formunun 2, 3, 4 ve 5. kısımlarında ise 7'li Likert ölçeği kullanılmıştır. Ölçekte, 1Kesinlikle katıliyorum, 2-Katılıyorum, 3-Kısmen katıliyorum, 4-Ne katıliyorum $\mathrm{Ne}$ katılmiyorum, 5-Kısmen katılmiyorum, 6-Katılmiyorum, 7-Kesinlikle katılmiyorum değerlendirmelerine karşılık gelmektedir.

\subsubsection{Araştırmada Kullanılan Ölçekler}

\subsubsection{Kurumsal Girişimcilik Ölçeği}

Genel olarak kurumsal girişimcilik literatürü incelenince kurumsal girişimciliği ölçmek amacıyla farklı ölçekler geliştirildiği ve kullanıldığı görülmektedir. Khandwalla tarafından 1976 yılında oluşturulan "Girişimcilik Yönelme Ölçeği" (Entrepreneurial Orientation Scale), Covin ve Slevin (1989) tarafından geliştirilen "Girişimcilik Oryantasyonu Ölçeği" ve Zahra (1991) tarafından geliştirilen Kurumsal Girişimcilik Ölçeği (Corporate Entrepreneuership Scale) bunlar arasında en sık kullanılanlardır. Çalışma kapsamında Guth ve Ginsberg'in (1990) kurumsal girişimcilikle ilgili çalışmasında ortaya konan kavramsal çerçeve işı̆̆ında kurumsal girişimciliği, girişimcilik eğiliminin davranışa yansımış hali ile analiz eden ölçekler dikkate alınmıştır.

Kurumsal girişimcilik ve yeniliğin işletme performansı ilişkisini esas alan bu çalışmada literatürde yer alan ve yukarıda adı geçen ölçekler ile literatürdeki çalışmalardan yararlanılarak (bu çalışmalar için bkz. Covin ve Slevin, 1989; Covin ve Slevin 1991; Fiş ve Çetindamar, 2007; Guth ve Ginsberg, 1990; Lumpkin ve Dess, 1996; Zahra, 1991) ve Lumpkin ve Dess'in (1996) beş boyutlu çalışmasına sadık kalınarak bir ölçek oluşturulmuştur.

Bu bağlamda Zahra vd. (2000), Zahra (1991), Zahra (1993a), Zahra ve Covin (1995), Zahra (1996), Şimşek vd. (2007), Ling vd. (2008), Heavey vd. (2009), Yiu ve Lau'nun (2008) çalışmalarından esinlenerek Fiş ve Wasti'nin (2009) Türkçeye çevirip tasarladığı kurumsal girişimcilik ölçeği kullanılmıştır. Bu çalışmada oluşturulan ölçek risk alma, yenilikçilik, proaktiflik, örgütsel yenilenme ve rekabetçi agresiflik olmak üzere beş boyuttan oluşmaktadır. Çalışmada, risk alma boyutu dört ifadeyle, yenilikçilik boyutu beş ifadeyle, proaktiflik boyutu dört ifadeyle, örgütsel yenilenme boyutu dört ifadeyle ve rekabetçi agresiflik boyutu dört ifadeyle ölçülmüştür.

\subsubsection{Yenilik Ölçeği}

İnovasyon ölçeği Calantone vd. (2002) tarafından geliştirilmiş, ölçeğin Türkçe'ye çevirisinde Alpkan vd. (2011), Özşahin vd. (2005) ve Erdil ve Kitapçı’nın (2007) çalışmalarından yararlanılmıştır.

\subsubsection{3. İşletme Performansı Ölçeği}

İşletme performansının ölçümü için stratejik yönetim disiplininde işletme etkinliği ve karlılığının arttırılmasına odaklanılması nedeniyle, daha çok nicel performans kriterlerinin kullanıldığını ve nicel performans kriterleri içerisinde de en sık kullanılanın finansal performans boyutu olduğu bilinmektedir (Bulut, 2007). Bu bağlamda, işletme performansını ölçmek için Phillips (1999) geliştirdiği, Fiş’in (2009) çeşitli araştırmalardan derlediği ve 
Türkçeye çevirdiği (Bulut, 2007; Li ve Zhang, 2007; Yiu ve Lau, 2008; Erkocaoğlan, 2012) işletme performansı ölçeği kullanılmıştır. Ölçeğin güvenirlik ve geçerlik çalışmaları yine araştırmacı tarafından yapılmış ve ölçeğin Türkiye'de kullanılabileceği sonucuna ulaşılmıştır.

\subsection{Araştırmanın Bulguları}

Bu bölümde SPSS 21.0 paket programı aracılığıyla elde edilen verilerin analizi yapılmıştır. İlk olarak verilerin güvenilirlik analizi sonuçları incelenmiştir. Sonrasında araştırmaya katılan katılımcıların demografik özelliklerinin incelendiği istatistiklere ve yorumlara yer verilmiştir. Daha sonra ise araştırmanın sorunsalını oluşturan değişkenlerle ilgili, analizler ile ilgili bulgular incelenmiştir.

\subsubsection{Güvenilirlik Testi Sonuçları}

Tablo 2: Güvenilirlik Testi Sonuçları Tablosu

\begin{tabular}{|l|c|c|}
\hline Ölçek & $\begin{array}{c}\text { Cronbach's Alpha } \\
\text { (Tutarlılık Katsayısı) }\end{array}$ & Ölçekteki İfade Sayısı \\
\hline Risk Alma Eğilimi &, 928 & 4 ifade \\
\hline Yenilikçilik &, 908 & 5 ifade \\
\hline Proaktiflik &, 907 & 4 ifade \\
\hline Örgütsel Yenilenme &, 907 & 4 ifade \\
\hline Rekabetçi Agresiflik &, 919 & 4 ifade \\
\hline Çevrenin Rekabetçi Yapısı &, 914 & 3 ifade \\
\hline Finansal Olmayan Performans &, 916 & 5 ifade \\
\hline Finansal Performans &, 921 & 5 ifade \\
\hline
\end{tabular}

Cronbach's Alpha değerlerinin ölçek çalışmalarında en az .70 ve üzeri olması gerektiği genel kabul görmektedir (Seçer, 2013:179). Güvenirlilik analizi sonucunda çalışmanın anketinin tüm boyutlarının Cronbach's Alpha değerleri yukarıda gösterildiği üzere oldukça güvenilir seviyede olduğu tespit edilmiştir.

\subsubsection{Katılımcıların Demografik Özelliklerine İlişkin Bilgiler}

Tablo 3: Katılımcıların Demografik Özelliklerine İlişkin Bilgiler Tablosu

\begin{tabular}{|lcclcc|}
\hline $\begin{array}{l}\text { Cinsiyet } \\
(\%)\end{array}$ & Frekans & Oran & Yaş Durumu & Frekans & Oran (\%) \\
Erkek & 142 & 48,3 & $20-25$ yaş & 108 & 36,7 \\
Kadın & 152 & 51,7 & $25-35$ yaş & 111 & 37,8 \\
& & & $35-40$ yaş & 54 & 18,4 \\
& & & 40 ve üzeri & 21 & 7,1 \\
Ĕğitim Düzeyi & Frekans & Oran & Çalışma Süresi & Frekans & Oran (\%) \\
$(\%)$ & & & & 156 & 53,1 \\
Lise & 98 & 33,3 & $1-5$ yıl & 93 & 31,6 \\
Önlisans & 116 & 39,5 & $6-10$ y1 & 35 & 11,9 \\
Lisans & 72 & 24,5 & $11-15$ yıl & 3,4 \\
Lisansüstü & 8 & 2,7 & 16 yıl ve üzeri & 10 & Oran (\%) \\
Kurum Alanı & Frekans & Oran & Unvan & Frekans & \\
(\%) & & & & & \\
Kamu & 111 & 37,8 & İdari Çalışan & 78 & 26,5 \\
Özel & 183 & 62,2 & Sağlı Çalışanı & 216 & 73,5 \\
\hline
\end{tabular}


Tanımlayıcı istatistik bazında katılımcıların demografik dağılımları ve profilleri Tablo 3'teki gibidir. Katılımcıların \%48,3'ünü temsil eden 142 kişi erkek, \%51,7'sini temsil eden 152 kişi de kadın katılımcı olmak üzere toplam 294 kişiden oluşmaktadır. Sağlık işletmelerinde, "Kurumsal Girişimcilik ve Yenilikçiliğin İşletme Performansı"na ilişsin araştırmaya katılan katılımcıların yaş grupları incelendiğinde; \%36,7'sini temsil eden 108 kişinin 20-25 yaş aralığında ve \%37,8'ini temsil eden 111 kişinin 25-35 yaş arasında, \%18,4,'ünü temsil eden 54 kişinin 35-40 yaş arası ve \%7,1'ini temsil eden 21 kişinin 40 yaş ve üzerinde olduğu görülmektedir.

Araştırmaya katılan kişilerin eğitim durumları incelendiğinde; \%33,3'ünü temsil eden 98 kişinin lise, \%39,5'ini temsil eden 116 kişinin önlisans, \%24,5'i temsil eden 72 kişinin lisans, \%2,7'sini temsil eden 8 kişinin lisansüstü düzeyinde eğitime sahip oldukları görülmüştür.

Araştırmaya katılan kişilerin çalışma süreleri incelendiğinde; \%53,1'i temsil eden 156 kişinin 1-5 y1l arası, \%31,6'sını temsil eden 93 kişinin 6-10 yıl arası, \%11,9'unu temsil eden 35 kişinin 11-15 yıl arası, \%3,4'ünü temsil eden 10 kişinin 16 yıl ve üzeri çalıştığı görülmüştür.

Araştırmaya katılan kişilerin çalışma alanları incelendiğinde; \%37,8'i temsil eden 111 kişinin kamu alanında, \%62,2'sini temsil eden 183 kişinin özel kesim alanında çalıştığı görülmüştür.

Araştırmaya katılan kişilerin unvanları incelendiğinde; \%26,5'i temsil eden 78 kişinin idari çalışan, \% 73,5'ini temsil eden 216 kişinin sağlık çalışanı olarak çalıştığı görülmüştür.

\subsubsection{Hipotezler ile İlgili Analizler}

Basit doğrusal regresyon analizi sonucunda yenilikçilik eğilimi boyutunun finansal performans ile anlamlı bir ilişkiye sahip olduğu bulunmuştur $\left(\mathrm{R}=, 50, \mathrm{R}^{2}=, 25, \mathrm{p}<, 01\right)$. Buna göre, yenilikçilik eğilimi finansal performanstaki toplam varyansın \%50'sini açıklamaktadır. Standardize edilmiş Beta katsayısı ve t değerleri incelendiğinde yenilikçilik eğiliminin finansal performansa pozitif ve anlamlı şekilde etki ettiği söylenebilir. Dolayısıyla, $\mathrm{H}_{1 \mathrm{a}}$ kabul edilmiştir.

Tablo 4: Yenilikçilik Eğiliminin Finansal Performans Üzerindeki Etkisi Üzerine Regresyon Analizi

\begin{tabular}{|l|c|c|c|c|c|}
\hline Değişken & B & Standart Hata & Beta & t & p \\
\hline Constant/Sabit & 1,335 &, 136 & & 9,809 &, 000 \\
\hline $\begin{array}{l}\text { Yenilikçilik } \\
\text { Eğilimi }\end{array}$ &, 422 &, 043 &, 499 & 9,815 &, 000 \\
\hline
\end{tabular}

Basit doğrusal regresyon analizi sonucunda yenilikçilik eğilimi boyutunun finansal olmayan performans ile anlamlı bir ilişkiye sahip olduğu bulunmuştur $\left(R=, 64, R^{2}=, 41, p<, 01\right)$. Buna göre, yenilikçilik eğilimi finansal olmayan performanstaki toplam varyansın \%41'ini açıklamaktadır. Standardize edilmiş Beta katsayısı ve t değerleri incelendiğinde yenilikçilik eğiliminin finansal olmayan performansa pozitif ve anlamlı şekilde etki ettiği söylenebilir. Dolayısıyla, $\mathrm{H}_{1 b}$ kabul edilmiştir.

Tablo 5: Yenilikçilik Eğiliminin Finansal Olmayan Performans Üzerindeki Etkisi Üzerine Regresyon Analizi

\begin{tabular}{|l|c|c|c|c|c|}
\hline Değişken & B & Standart Hata & Beta & t & p \\
\hline Constant/Sabit & 1,023 &, 121 & & 8,466 &, 000 \\
\hline $\begin{array}{l}\text { Yenilikçilik } \\
\text { Eğilimi }\end{array}$ &, 540 &, 038 &, 639 & 14,144 &, 000 \\
\hline
\end{tabular}


Basit doğrusal regresyon analizi sonucunda proaktiflik boyutunun finansal performans ile anlamlı bir ilişkiye sahip olduğu bulunmuştur $\left(\mathrm{R}=, 54, \mathrm{R}^{2}=, 30, \mathrm{p}<, 01\right)$. Buna göre, proaktiflik finansal performanstaki toplam varyansın \%30'unu açıklamaktadır. Standardize edilmiş Beta katsayısı ve $\mathrm{t}$ değerleri incelendiğinde proaktifliğin finansal performansa pozitif ve anlamlı şekilde etki ettiği söylenebilir. Dolayısıyla, $\mathrm{H}_{2 \mathrm{a}}$ kabul edilmiştir.

Tablo 6: Proaktifliğin Finansal Performans Üzerindeki Etkisi Üzerine Regresyon Analizi

\begin{tabular}{|l|c|c|c|c|c|}
\hline \multicolumn{1}{|c|}{ Değişken } & B & Standart Hata & Beta & t & p \\
\hline Constant/Sabit & 1,246 &, 131 & & 9,517 &, 000 \\
\hline Proaktiflik &, 452 &, 041 &, 543 & 11,004 &, 000 \\
\hline
\end{tabular}

Basit doğrusal regresyon analizi sonucunda proaktiflik boyutunun finansal olmayan performans ile anlamlı bir ilişkiye sahip olduğu bulunmuştur $\left(\mathrm{R}=, 65, \mathrm{R}^{2}=, 42, \mathrm{p}<, 01\right)$. Buna göre, proaktiflik finansal olmayan performanstaki toplam varyansın \%42'sini açıklamaktadır. Standardize edilmiş Beta katsayısı ve t değerleri incelendiğinde proaktifliğin finansal olmayan performansa pozitif ve anlamlı şekilde etki ettiği söylenebilir. Dolayısıyla, $\mathrm{H}_{2 b}$ kabul edilmiştir.

Tablo 7: Proaktifliğin Finansal Olmayan Performans Üzerindeki Etkisi Üzerine Regresyon Analizi

\begin{tabular}{|l|c|c|c|c|c|}
\hline \multicolumn{1}{|c|}{ Değişken } & B & Standart Hata & Beta & t & p \\
\hline Constant/Sabit & 1,024 &, 119 & & 8,591 &, 000 \\
\hline Proaktiflik &, 537 &, 037 &, 645 & 14,363 &, 000 \\
\hline
\end{tabular}

Basit doğrusal regresyon analizi sonucunda örgütsel yenilenme boyutunun finansal performans ile anlamlı bir ilişkiye sahip olduğu bulunmuştur $\left(\mathrm{R}=, 56, \mathrm{R}^{2}=, 31, \mathrm{p}<, 01\right)$. Buna göre, örgütsel yenilenme finansal performanstaki toplam varyansın \%31'ini açıklamaktadır. Standardize edilmiş Beta katsayısı ve t değerleri incelendiğinde örgütsel yenilenmenin finansal performansa pozitif ve anlamlı şekilde etki ettiği söylenebilir. Dolayısıyla, $\mathrm{H}_{3 \mathrm{a}}$ kabul edilmiştir

Tablo 8: Örgütsel Yenilenmenin Finansal Performans Üzerindeki Etkisi Üzerine Regresyon Analizi

\begin{tabular}{|l|c|c|c|c|c|}
\hline Değişken & B & Standart Hata & Beta & t & p \\
\hline Constant/Sabit & 1,150 &, 135 & & 8,548 &, 000 \\
\hline $\begin{array}{l}\text { Örgütsel } \\
\text { Yenilenme }\end{array}$ &, 498 &, 044 &, 556 & 11,393 &, 000 \\
\hline
\end{tabular}

Basit doğrusal regresyon analizi sonucunda örgütsel yenilenme boyutunun finansal olmayan performans ile anlamlı bir ilişkiye sahip olduğu bulunmuştur $\left(R=, 67, \mathrm{R}^{2}=, 44, \mathrm{p}<, 01\right)$. Buna göre, örgütsel yenilenme finansal olmayan performanstaki toplam varyansın \%44'ünü açıklamaktadır. Standardize edilmiş Beta katsayısı ve $\mathrm{t}$ değerleri incelendiğinde örgütsel yenilenmenin finansal olmayan performansa pozitif ve anlamlı şekilde etki ettiği söylenebilir. Dolayısıyla, $\mathrm{H}_{3 \mathrm{~b}}$ kabul edilmiştir.

Tablo 9: Örgütsel Yenilenmenin Finansal Olmayan Performans Üzerindeki Etkisi Üzerine Regresyon Analizi

\begin{tabular}{|l|c|c|c|c|c|}
\hline Değissken & B & Standart Hata & Beta & t & p \\
\hline Constant/Sabit &, 900 &, 121 & & 7,436 &, 000 \\
\hline $\begin{array}{l}\text { Örgütsel } \\
\text { Yenilenme }\end{array}$ &, 595 &, 039 &, 665 & 15,161 &, 000 \\
\hline
\end{tabular}


Basit doğrusal regresyon analizi sonucunda risk alma eğilimi boyutunun finansal performans ile anlamlı bir ilişkiye sahip olduğu bulunmuştur $\left(\mathrm{R}=, 35, \mathrm{R}^{2}=, 12, \mathrm{p}<, 01\right)$. Buna göre, risk alma eğilimi finansal performanstaki toplam varyansın \%12'sini açıklamaktadır. Standardize edilmiş Beta katsayısı ve t değerleri incelendiğinde risk alma eğiliminin finansal performansa pozitif ve anlamlı şekilde etki ettiği söylenebilir. Dolayısıyla, $\mathrm{H}_{4 a}$ kabul edilmiştir.

Tablo 10: Risk Alma Eğiliminin Finansal Performans Üzerindeki Etkisi Üzerine Regresyon Analizi

\begin{tabular}{|l|c|c|c|c|c|}
\hline Değişken & B & Standart Hata & Beta & t & p \\
\hline Constant/Sabit & 1,553 &, 165 & & 9,393 &, 000 \\
\hline $\begin{array}{l}\text { Risk Alma } \\
\text { Eğilimi }\end{array}$ &, 309 &, 049 &, 345 & 6,289 &, 000 \\
\hline
\end{tabular}

Basit doğrusal regresyon analizi sonucunda risk alma eğilimi boyutunun finansal olmayan performans ile anlamlı bir ilişkiye sahip olduğu bulunmuştur $\left(\mathrm{R}=, 44, \mathrm{R}^{2}=, 19, \mathrm{p}<, 01\right)$. Buna göre, risk alma eğilimi finansal olmayan performanstaki toplam varyansın \%19'unu açıklamaktadır. Standardize edilmiş Beta katsayısı ve t değerleri incelendiğinde risk alma eğiliminin finansal olmayan performansa pozitif ve anlamlı şekilde etki ettiği söylenebilir. Dolayısıyla, $\mathrm{H}_{4 \mathrm{~b}}$ kabul edilmiştir.

Tablo 11: Risk Alma Eğiliminin Finansal Olmayan Performans Üzerindeki Etkisi Üzerine Regresyon Analizi

\begin{tabular}{|l|c|c|c|c|c|}
\hline Değişken & B & Standart Hata & Beta & t & p \\
\hline Constant/Sabit & 1,319 &, 159 & & 8,315 &, 000 \\
\hline $\begin{array}{l}\text { Risk Alma } \\
\text { Eğilimi }\end{array}$ &, 391 &, 047 &, 437 & 8,296 &, 000 \\
\hline
\end{tabular}

Basit doğrusal regresyon analizi sonucunda rekabetçi agresiflik eğilimi boyutunun finansal performans ile anlamlı bir ilişkiye sahip olduğu bulunmuştur $\left(R=, 60, R^{2}=, 36, p<, 01\right)$. Buna göre, rekabetçi agresiflik eğilimi finansal performanstaki toplam varyansın \%36'sını açıklamaktadır. Standardize edilmiş Beta katsayısı ve $t$ değerleri incelendiğinde rekabetçi agresiflik eğiliminin finansal performansa pozitif ve anlamlı şekilde etki ettiği söylenebilir. Dolayısıyla, $\mathrm{H}_{5 \mathrm{a}}$ kabul edilmiştir.

Tablo 12: Rekabetçi Agresiflik Eğiliminin Finansal Performans Üzerindeki Etkisi Üzerine Regresyon Analizi

\begin{tabular}{|l|c|c|c|c|c|}
\hline Değişken & B & Standart Hata & Beta & t & p \\
\hline Constant/Sabit &, 964 &, 135 & & 7,142 &, 000 \\
\hline $\begin{array}{l}\text { Rekabetçi } \\
\text { Agresiflik } \\
\text { Eğilimi }\end{array}$ &, 526 &, 041 &, 600 & 12,768 &, 000 \\
\hline
\end{tabular}

Basit doğrusal regresyon analizi sonucunda rekabetçi agresiflik eğilimi boyutunun finansal olmayan performans ile anlamlı bir ilişkiye sahip olduğu bulunmuştur $\left(\mathrm{R}=, 53, \mathrm{R}^{2}=, 28\right.$, $\mathrm{p}<, 01)$. Buna göre rekabetçi agresiflik eğilimi finansal olmayan performanstaki toplam varyansın \%28'ini açıklamaktadır. Standardize edilmiş Beta katsayısı ve t değerleri incelendiğinde rekabetçi agresiflik eğiliminin finansal olmayan performansa pozitif ve anlamlı şekilde etki ettiği söylenebilir. Dolayısıyla, $\mathrm{H}_{5 \mathrm{~b}}$ kabul edilmiştir. 
Tablo 13: Rekabetçi Agresiflik Eğiliminin Finansal Olmayan Performans Üzerindeki Etkisi Üzerine Regresyon Analizi

\begin{tabular}{|l|c|c|c|c|c|}
\hline Değişken & B & Standart Hata & Beta & t & p \\
\hline Constant/Sabit & 1,212 &, 139 & & 8,709 &, 000 \\
\hline $\begin{array}{l}\text { Rekabetçi } \\
\text { Agresiflik } \\
\text { Eğilimi }\end{array}$ &, 438 &, 041 &, 528 & 10,576 &, 000 \\
\hline
\end{tabular}

\section{Sonuç ve Öneriler}

Son yıllarda sağlık hizmetlerinde teknolojik ve yenilik bakımından süreklilik arz eden bir gelişim ve değişim süreci yaşanmaktadır. Sunulan hizmetlerin insan ve toplum sağlığının korunması ve geliştirilmesine yönelik amaçlara göre şekillendirildiği sağlık hizmetleri sektörü, gelişen teknoloji ve artan yeniliklerin de etkisinin yanı sıra özellikle finansal kaynakların yetersizliği nedeniyle hizmet sunumu ve yönetim açısından farklı stratejik plan ve yönetimlerle gelişen bir sektör halini almıştır. Sağlık hizmeti sunan işletmeler farklı strateji ve yöntemlerle hedeflerine erişim ve rekabetin yoğun olduğu sektörde lider ve pazar payından daha fazla pay elde etmek için çalışmaktadır.

Bu noktada, sağlık yönetimi ve hizmet gelişimi alanında eğitim almış, inisiyatif kullanabilen, inovatif düşünme yeteneğine vakıf, sürekli gelişime ve yeniliği önem veren, akılcı riskler alabilen, öngörüsü yüksek yöneticilerin ve idari çalışanların sektörde daha fazla yer alması gerektiği yapılan çalışmalar sonucu öngörülmektedir.

Araştırmanın sonucunda, sağlık işletmelerinde kurumsal girişimcilik ve yenilik kavramının henüz tam anlamıyla bilinmediği ve kurumsal girişimcilik ve yenilik kavramının sağlık işletmelerinin performansı üzerinde olumlu bir etkiye sahip olduğu belirlenmiştir. Araştırmanın sonuçlarından yola çıkarak sağlık alanında kurumsal girişimcilik ve yenilik faaliyetlerinden yararlanmak için inovasyon, risk yönetimi, AR-GE, stratejik yönetim gibi alanlarda hizmet içi eğitimler planlanmalı ve sürekli eğitim ile güncellenmelidir. İnovasyon çalışmaları desteklenmeli ve cesaretlendirilmelidir. Müşteri taleplerini karşılayacak kaliteli hizmet sunabilmek ve rekabet üstünlüğü sağlayarak pazarda değer yaratmak için kurumsal girişimcilik ve yenilik faaliyetlerinde kurum ve işletmelerin yönetim kademelerinin her düzeyinde farkındalık yaratılması için çalışmalar yapılmalıdır. Bu çalışmanın kısıtları olarak Batman ilindeki dört hastanedeki toplam 294 kişiye uygulanmış olmasıdır. Bundan sonraki çalışma yapacaklara daha farklı hastanelerde ve kurumlarda daha çok katılımcı ile çalışma yapmaları önerilir.

\section{Kaynakça}

Ağca, V. (2005). İç Girişimcilik Yapısı ve Firma Performansına Etkileri: Denizli Tekstil Sektöründeki Firmalarda Bir Araştırma. Afyon Kocatepe Üniversitesi Sosyal Bilimler Enstitüsü, Yayımlanmamış Doktora Tezi, Afyon.

Alpkan, L., Ergün, E., Bulut, Ç., \& Y1lmaz, C. (2011). Şirket Girişimciliğinin Şirket Performansına Etkileri. Doğuş Üniversitesi Dergisi, 6(2), 175-189.

Antoncic, B., \& Hisrich, R. D. (2001). Intrapreneurship: Construct Refinement and CrossCultural Validation. Journal of Business Venturing, 16(5), 495-527.

Aytaç, Ö. (2006). Girişimcilik: Sosyo-Kültürel Bir Perspektif. Dumlupınar Üniversitesi Sosyal Bilimler Dergisi, (15). 
Baki, B., \& Ustasüleyman, T. (2001). Kurumsal Kaynak Planlaması (ERP) Yazılımları ve Performans Ölçütleri. Verimlilik Dergisi, 69-80.

Bakoğlu, E. (2001). Örgütsel Performans Kavramı ve Gelişimi. Öneri Dergisi, 4(15), 39-45.

Boyne, G. A. (2003). Sources of Public Service Improvement: A Critical Review and Research Agenda. Journal of Public Administration Research and Theory, 13(3), 367-394.

Bulut, Ç. (2007). Stratejik Oryantasyonlar ve Firma Performanst. Gebze Yüksek Teknoloji Enstitüsü, Sosyal Bilimler Enstitüsü (Doctoral dissertation, Doktora Tezi, Gebze).

Bulut, Ç., \& Yilmaz, C. (2008). Innovative Performance Impacts of Corporate Entrepreneurship: An Empirical Research in Turkey. HYPOTHESIS, 16, 17.

Bulut, Ç., Aktan, B., Yılmaz, S., \& Fiş, A. M. (2008) Kurumsal Gırışımçılık: Kavramsal Yapı Üzerıne Bir Tartışma. Journal Of Yaşar University, 3(10), 1389-520.

Carrier, C. (1996). Intrapreneurship in Small Businesses: An Exploratory Study. Entrepreneurship Theory and Practice, 21(1), 5-20.

Covin, J. G., \& Slevin, D. P. (1988). The Influence of Organization Structure on The Utility of An Entrepreneurial Top Management Style. Journal of Management Studies, 25(3), $217-$ 234.

Covin, J. G., \& Slevin, D. P. (1989). Strategic Management of Small Firms in Hostile and Benign Environments. Strategic Management Journal, 10(1), 75-87.

Covin, J. G., \& Slevin, D. P. (1991). A Conceptual Model of Entrepreneurship as Firm Behavior. Entrepreneurship Theory and Practice, 16(1), 7-26.

Dess, G. G., Ireland, R. D., Zahra, S. A., Floyd, S. W., Janney, J. J., \& Lane, P. J. (2003). Emerging Issues in Corporate Entrepreneurship. Journal of Management, 29(3), 351378.

Drucker, P. (2014). Innovation and Entrepreneurship. Routledge.

Durna, U. (2002). Yenilik ve Yakın Kavramların Tanımlanması., Nobel Yayın Dağıtım.

Erdil, O., \& Kitapçı, H. (2007). TKY Araçlarının Kullanımı ve Firma Yenilikçiliğinin Yeni Ürün Geliştirme Hızı ve İşletme Performansına Etkisi. Atatürk Üniversitesi İktisadi ve Idari Bilimler Dergisi, 21(1), 233-245.

Erkocaoğlan, E. (2012). Gelişmekte olan piyasalarda sermaye türlerinin kurumsal girişimcilik yoluyla firma performansina etkisi: İMKB'ye kote firmalar üzerine bir araştırma. Çukurova Üniversitesi Sosyal Bilimler Enstitüsü, Yayımlanmamış Doktora Tezi, Adana.

Fiş, A. M., \& Wasti, S. A. (2009). Örgüt kültürü ve girişimcilik yönelimi ilişkisi. METU Studies In Development (Muhan Soysal Special Issue), 35, 127-164.

Fiş, A.M. ve Çetindamar, D. (2007). Girişimcilik Oryantasyonu, Kurum İçi Girişimcilik ve Bağlı Ölçeklerin Türkçede Geçerlemesi, XV. Ulusal Yönetim ve Organizasyon Kongresi, Sakarya

Goodale, J. C., Kuratko, D. F., Hornsby, J. S., \& Covin, J. G. (2011). Operations Management and Corporate Entrepreneurship: The Moderating Effect of Operations Control on The Antecedents of Corporate Entrepreneurial Activity in Relation to Innovation Performance. Journal of Operations Management, 29(1-2), 116-127.

Göztur, E., (2000), Performans Yönetim Sistemi ve Amaçlara Göre Yönetim, Yayınlanmamış Yüksek Lisans Tezi, İstanbul: Yıldız Teknik Üniversitesi Sosyal Bilimler Enstitüsü.

Gries, T., \& Naudé, W. (2011). Entrepreneurship and Human Development: A Capability Approach. Journal of Public Economics, 95(3-4), 216-224.

Guth, W. D., \& Ginsberg, A. (1990). Guest Editors' Introduction: Corporate Entrepreneurship. Strategic Management Journal, 5-15.

Haber, S., \& Reichel, A. (2005). Identifying Performance Measures of Small Ventures-The Case of The Tourism Industry. Journal of Small Business Management, 43(3), 257-286. 
Hayton, J. C., \& Kelley, D. J. (2006). A Competency-Based Framework for Promoting Corporate Entrepreneurship. Human Resource Management: Published in Cooperation with The School of Business Administration, The University of Michigan And in Alliance with The Society of Human Resources Management, 45(3), 407-427.

Hisrich, R., Peters, M.P. \& Shepherd, D.A. (2005). Entrepreneurship. McGraw-Hill Co.

Johansson, F. (2013). İnovasyon Fikirleri Gerçekleştirilir. F. Johansson içinde, D. (Çev). Tayanç Yaratıcılık ve Inovasyon: Mecidi Etkisi Yaratmak(s. 30)., MediaCat Kitapları.

Kao, J. (1989). Entrepreneurship Creativity \& Organization., Prentice Hall Inc.

Khandwalla, P. N. (1976). Some Top Management Styles, Their Context and Performance. Organization and Administrative Sciences, 7(4), 21-51.

Landström, H., Harirchi, G., \& Åström, F. (2012). Entrepreneurship: Exploring the Knowledge Base. Research Policy, 41(7), 1154-1181.

Lumpkin, G. T., \& Dess, G. G. (1996). Clarifying the Entrepreneurial Orientation Construct and Linking It to Performance. Academy of Management Review, 21(1), 135-172.

Lumpkin, G. T., \& Dess, G. G. (2001). Linking Two Dimensions of Entrepreneurial Orientation to Firm Performance: The Moderating Role of Environment and Industry Life Cycle. Journal of Business Venturing, 16(5), 429-451.

Mawer, D. H. (2003). Enlivening Analysis Through Performance: Practising Set Theory. British Journal of Music Education, 20(3), 257-276.

Morrison, A., Rimmington, M. \& Williams, C. (2001). Entrepreneurship in The Hospitality, Tourism \& Leisure Industries. Antony Rowe Ltd.

Okumuş, F., \& Avc1, U. (Eds.). (2008). Turizm İşletmelerinde Çăğdaş Yönetim Teknikleri. Detay Yayıncilik.

Özşahin, M., Ciğerim, E., \& Gök, M. Ş. (2005). Rekabet Edebilirlik ve Firma Performansı İlişkisi Üzerine Bir Saha Araştırması. Gazi Üniversitesi İktisadi ve İdari Bilimler Fakültesi Dergisi, 7(1), 143-155.

Reiner, G. (2005). Customer-oriented improvement and evaluation of supply chain processes supported by simulation models. International journal of production economics, 96(3), 381-395.

Rimmington, M., Williams, C., \& Morrison, A. (2009). Entrepreneurship in The Hospitality, Tourism and Leisure Industries. Routledge.

Romero-Martínez, A. M., Fernández-Rodríguez, Z., \& Vázquez-Inchausti, E. (2010). Exploring Corporate Entrepreneurship in Privatized Firms. Journal of World Business, 45(1), 2-8.

Sathe, Vijay, (2003). Corporate Entrepreneurship Top Managers and New Business Creation, Cambridge University Press, First Edition.

Seçer, İ. (2013). SPSS ve LISREL ile pratik veri analizi. Ankara: Anı Yayıncılı.

Sheu, H. J., \& Lo, S. F. (2005). A New Conceptual Framework Integrating Environment into Corporate Performance Evaluation. Sustainable Development, 13(2), 79-90.

Tekin, M. (2014). Girişimcilik ve Küçük Işsletme Yöneticiliği, Günay Ofset, 11. Bask1, Konya.

Tekin, M. (2016). Hayallerin Gerçeğe Dönüşümü Girişimcilik, Günay Ofset, 7. Baskı, Konya.

Thakur, R., Hsu, S. H., \& Fontenot, G. (2012). Innovation in Healthcare: Issues and Future Trends. Journal of Business Research, 65(4), 562-569.

Thomson, N., \& Mcnamara, P. (2001). Achieving Post-Acquisition Success: The Role of Corporate Entrepreneurship. Long Range Planning, 34(6), 669-697.

Van De Ven, A. H., Polley, D. E., Garud, R., \& Venkataraman, S. (1999). Building an Infrastructure for The Innovation Journey. The Innovation Journey, 149-180.

Yiu, N. L. M. (2008). U.S. Patent Application No. 29/232, 765.

Zahra, S. A. (1991). Predictors and Financial Outcomes of Corporate Entrepreneurship: An Exploratory Study. Journal of Business Venturing, 6(4), 259-285. 
Zahra, S. A. (1996). Goverance, Ownership, And Corporate Entrepreneurship: The Moderating Impact of Industry Technological Opportunities. Academy of Management Journal, 39(6), 1713-1735.

Zahra, S. A. (2005). Entrepreneurial Risk Taking in Family Firms. Family Business Review, 18(1), 23-40.

Zahra, S. A., \& Covin, J. G. (1995). Contextual Influences on The Corporate EntrepreneurshipPerformance Relationship: A Longitudinal Analysis. Journal of Business Venturing, 10(1), 43-58.

Zehir, C., Müceldili, B., \& Zehir, S. (2012). The Impact of Corporate Entrepreneurship on Organizational Citizenship Behavior And Organizational Commitment: Evidence From Turkey Smes. Procedia-Social and Behavioral Sciences, 58, 924-933. 